\title{
Productivity and life history of Laminaria longicruris at its southern limit in the Western Atlantic Ocean
}

\author{
B. Egan*, C. Yarish \\ Department of Ecology and Evolutionary Biology, University of Connecticut, 641 Scofieldtown Road, Stamford, \\ Connecticut 06903, USA
}

\begin{abstract}
The seasonal population dynamics of Laminaria longicruris de la Pyl. were studied in Long Island Sound (Connecticut, USA). Linear growth rates were minimal during August and September, subsequently increased through the remainder of the year and reached a maximum $\left(2.5 \mathrm{~cm} \mathrm{d^{-1 }}\right)$ in May. Productivity per plant (fresh weight) was maximal January to May (11.4 to $15.7 \mathrm{mg} \mathrm{g}^{-1} \mathrm{~d}^{-1}$ ); productivity $\mathrm{m}^{-2}$ was maximum in May $\left(110.53 \mathrm{~g} \mathrm{~m}^{-2} \mathrm{~d}^{-1}\right.$ in 1986 and $413.32 \mathrm{~g} \mathrm{~m}^{-2} \mathrm{~d}^{-1}$ in 1987$)$. Production was $10.6 \mathrm{~kg} \mathrm{~m}^{-2}$ in 1986 and was estimated to have been 46 to $50 \mathrm{~kg} \mathrm{~m}^{-2}$ in 1987 . Maximum standing crop was observed in May (1986: $24 \mathrm{~kg} \mathrm{~m}^{-2} ; 1987: 47 \mathrm{~kg} \mathrm{~m}^{-2}$ ). Maximum densities of new recruits were 1000 ind. $\mathrm{m}^{-2}$. Densities of plants with blades $>50 \mathrm{~g}$ were 92 and 167 plants $\mathrm{m}^{-2}$ in January and May, respectively. Carbon and nitrogen contents were minimal and maximal, respectively, in winter; the reverse was true for summer measurements. Highest percentages of fertile plants were observed during October to December. Succession in generations of plants behaving as either annuals or biennials is also noted and discussed.
\end{abstract}

\section{INTRODUCTION}

Members of the genus Laminaria comprise an important group of benthic marine macrophytes, both ecologically (Mann 1972b. Chapman \& Craigie 1977, Chapman 1987) and economically (Okazaki 1971. Chapman \& Chapman 1980, Pringle \& Sharp 1980, Tseng 1981, Brinkhuis et al. 1987). These kelps possess a fairly low maximum temperature tolerance and consequently, are limited to temperate and polar regions in the northern, and temperate regions in the southern, hemispheres (Kain 1979, Hoek 1982, Luning 1985. Egan \& Yarish 1988).

Laminaria longicruris de la Pyl. only occurs in the North Atlantic Ocean (Egan \& Yarish 1988). It is most commonly found in the northwestern regions of this ocean and is at its southern geographical limit proximal to the northern shores of eastern Long Island Sound, USA (Egan \& Yarish 1988).

Laminaria longicruris shares certain morphological characteristics with Laminaria saccharina (L.) Lamour. Both species possess a simple or undivided blade

\footnotetext{
- Deceased February 1990
}

(c) Inter-Research/Printed in Germany (lamina) and their morphological development is similar. However, differences exist in the stipe morphologies of the 2 species (Wilce 1965). The stipes of $L$. longicruris elongate considerably and become hollow at their distal regions, at the end of the first year or during the second year of growth (Egan \& Yarish 1988). The solid stipes of $L$. saccharina are usually much shorter (Yarish et al. 1990). L. longicruris has been considered to be conspecific with L. saccharina (Chapman 1974, Lüning et al. 1978). However, data presented by Egan \& Yarish (1988), Egan et al. (1990) and Yarish et al. (1990) show that there are very distinctive characters separating the 2 forms, especially with regards to stipe morphology.

Sub-tidal areas inhabited by Laminaria spp. are characterized by high primary productivity and large biomass (see review by Kain 1979). The most extensive data on kelp productivity have been presented for the mid-range of their latitudinal distribution (Mann 1972a, b. Chapman 1984, 1987, Gendron 1985). Information on populations at or near their southern distributional ranges is limited. Brady-Campbell et al. (1984) found that seasonal primary productivity patterns of $L$. saccharina near its southern limit in Rhode Island, USA, 
paralleled those presented for more northerly locations. Previously, no information on seasonal primary production of $L$. longicruris at its southern boundary has been presented despite extensive kelps beds along the Connecticut coast (Yarish \& Egan 1989).

In the following study we report seasonal measurements and observations on growth rates, standing crop and productivity, sorus formation, nutrient status and morphological development of Laminaria longicruris at its southern limit in the Western Atlantic Ocean. We subsequently compare these data with those presented for both $L$. saccharina and $L$. longicruris from the North Atlantic, as well as kelp species from other regions

Mann \& Kirkman (1981) proposed that the calculation of production on plants brought back to the laboratory offered a much less cumbersome approach to measuring productivity in kelp beds than field measurements. Although their new technique was initially tested on Ecklonia radiata (C. Ag.) J. Agardh from the southwest coast of Western Australia, the authors expressed little doubt about its applicability to Laminaria spp. Mann \& Mann (1981) compared this biomass model with exponential and chordal models. In a later study, Gendron (1985) examined the differences between these models during 3 consecutive $3 \mathrm{wk}$ periods for $L$. longicruris from the Baie des Chaleurs, Quebec, Canada. We adopted Mann \& Kirkman's (1981) technique during our study, and to our knowledge it is the first time it has been applied to an annual study of Laminaria.

\section{MATERIAL AND METHODS}

Site description. Long Island Sound (LIS) is situated $\left(41^{\circ} 10^{\prime} 85^{\prime \prime} \mathrm{N}, 72^{\circ} 04^{\prime} \mathrm{W}\right)$ in a densely populated and highly industrialized region of southern New England, USA (Fig. 1). The ca $200 \times 39$ (widest) km embayment is connected on the west to New York Harbour via the East River and opens to the Atlantic Ocean on the east. Depths range from $100 \mathrm{~m}$ in the eastern end to $35 \mathrm{~m}$ in the central and western basins (Riley 1959, 1961). Black Ledge, Groton, Connecticut was selected as study site because it has one of the most extensive Laminaria populations in LIS. The ledge is located in a moderately exposed area $1 \mathrm{~km}$ offshore and to the east of the mouth of the Thames River Estuary (Fig. 1). The subtidal study site, which is at $4 \mathrm{~m}$ below MLW and has an area of ca $1 \mathrm{~km}^{2}$, is exposed to currents of $50 \mathrm{~cm} \mathrm{~s}^{-1}$ during peak ebb and flood tides (Egan \& Yarish 1988). The L. longicruris meadow was sampled by a stratified random sampling technique.

Morphometric data. One hundred plants were tagged in the subtidal using either forester's plastic tape or potted plant plastic identification stakes tied to the bases of their stipes. All tagged plants were selected for approximate uniform size and with stipe lengths at least $30 \mathrm{~cm}$ long. Monthly morphometric measurements (blade length and width, stipe length and linear meristematic growth) were made in situ, using SCUBA, from December 1984 to August 1985. Meristematic growth rates were determined by using the hole-punch technique of Parke (1948). Holes $(0.5 \mathrm{~cm}$ diam.) were punched $10.0 \mathrm{~cm}$ above the stipe-blade juncture at each site visit.

The sampling procedures of Mann \& Kirkman (1981) were employed from August 1985 to October 1986, and in January 1987 and May 1987. Sixty plants of approximate uniform size were selected and tagged each month. Different coloured tags were used each month. Holes were punched in the blades $10.0 \mathrm{~cm}$ above the stipe-blade junctures. On each subsequent visit, all

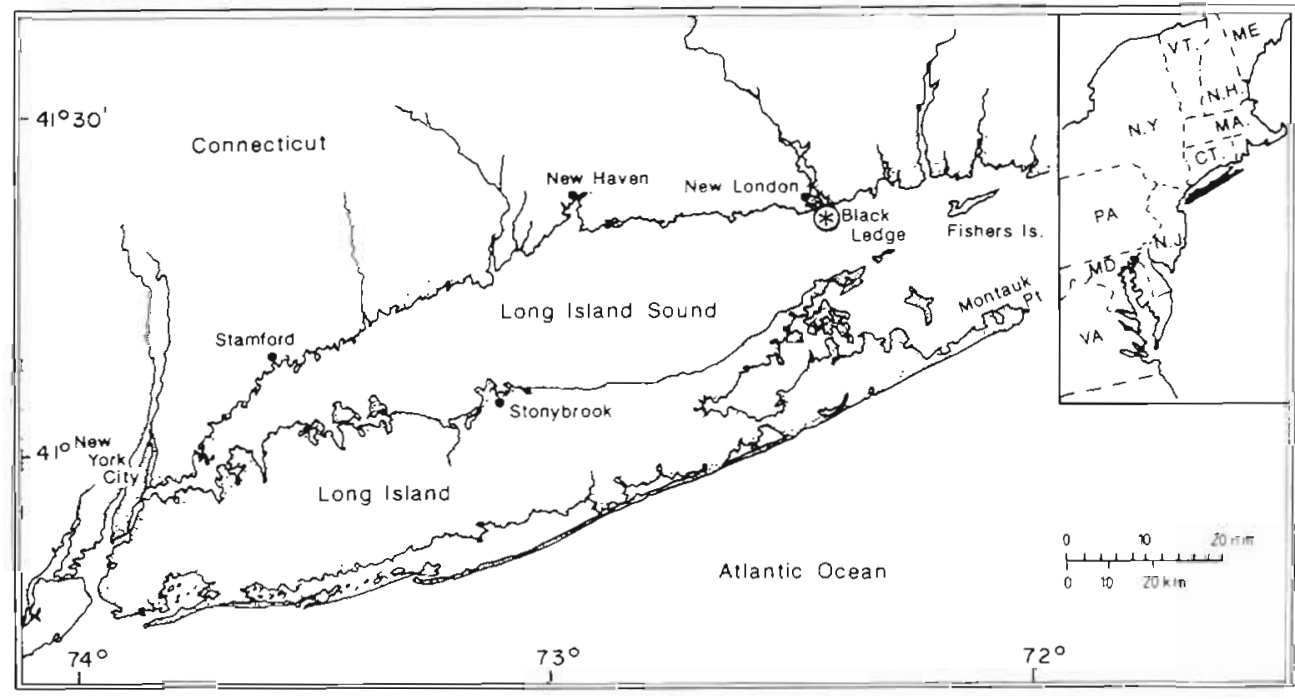

Fig. 1 Location of Black Ledge study site in eastern Long Island Sound, USA 
Table 1. Laminaria longicruris. Seasonal variability of wet/dry weight ratios (slope of linear regression model) for blades, stipes, holdfasts, and total weight of plants from Long Island Sound. There were no significant differences $(p \geqslant 0.05 ; t$-test) between wet/dry wt ratio of plants sampled in April and July

\begin{tabular}{|lrrcr|}
\hline Month & Blade & Stipe & Holdfast & Total \\
\hline Jan & 11.8 & 11.0 & 23.0 & 11.9 \\
Apr & 9.6 & 8.5 & 17.7 & 9.7 \\
Jul & 17.7 & 14.3 & 33.9 & 17.5 \\
\hline
\end{tabular}

plants previously tagged were harvested and returned to the laboratory for measurements. Observations on blade and stipe morphology as well as sorus production were also documented.

Water temperatures were measured during each site visit with a YSI (Yellow Springs Instruments, Yellow Springs, OH, USA) Model 43TD Tele-thermometer. Light measurements at the site have been reported elsewhere (Yarish \& Egan 1987).

Discs $(0.5 \mathrm{~cm}$ diameter $)$ were punched from the centre of 10 blades $12 \mathrm{~cm}$ above the blade-stipe juncture for each month. The use of tissue from this particular plant region reduces plant-to-plant variability (Lee $\&$ Brinkhuis 1986). The discs were washed thoroughly with de-ionized, distilled water. They were then ovendried at $60^{\circ} \mathrm{C}$ for $48 \mathrm{~h}$ and analyzed in either a Carlo Erba Model 1106 or 1500 Elemental Analyzer to determine the percentages of carbon and nitrogen present.

Dry weight to wet weight ratios were determined for plants harvested in January, April, and July 1986 by a linear regression model. Holdfasts, stipes and blades were sectioned and weighed. They were then wrapped in aluminium foil and oven-dried for $5 \mathrm{~d}$ at $60^{\circ} \mathrm{C}$. Ratios are presented in Table 1.

Biomass and density data. Six $0.25 \mathrm{~m}^{2}$ quadrats of Laminaria longicruris ( $>1 \mathrm{~cm}$ ) were harvested during each monthly site visit. The following data were col- lected in the laboratory for each quadrat: plant density (regardless of age class), holdfast, stipe and blade weights (fresh weights with excess water having been shaken from each plant section prior to weighing).

Productivity data. Productivity data were collected for the tagged plants returned to the laboratory each month after August 1985. Only plants with blades $\geqslant$ $50 \mathrm{~g}$ were used for productivity assessments. (Approximate blade dimensions of a plant [ca 1 yr old] with a blade $=50 \mathrm{~g}$ were $120 \times 17 \mathrm{~cm}$ in January 1987). The protocols used in productivity determinations were those presented by Mann \& Kirkman (1981) and Kirkman (1984)

\section{RESULTS}

\section{Growth of Laminaria Iongicruris}

The seasonal patterns in meristematic growth rates of Laminaria longicruris in LIS were similar during both years (Fig. 2). Highest linear growth rates occurred during spring $\left(2.5 \mathrm{~cm} \mathrm{~d}^{-1}\right)$. Water temperatures during the rapid-growth periods were $10^{\circ} \mathrm{C}$ (May 1985) and $14{ }^{\circ} \mathrm{C}$ (May 1986) (Fig. 2). Growth decreased from June to September as water temperatures reached 20 to $23^{\circ} \mathrm{C}$. The lowest linear growth rate $\left(0.1 \mathrm{~cm} \mathrm{~d}^{-1}\right)$ occurred during September 1985; the lowest linear growth rate of 1986 (0.5 $\left.\mathrm{cm} \mathrm{d}^{-1}\right)$ occurred during August. Faster growth resumed during the autumn.

In contrast, maximum growth as $\mathrm{mg} \mathrm{g}^{-1} \mathrm{~d}^{-1}$ (15.5 to 15.9) occurred during winter (Fig. 3) when water temperatures $\left(2\right.$ to $3^{\circ} \mathrm{C}$ ) were lowest (Fig, 2). Relatively high growth values were maintained into spring, with lowest values ( 0.7 to $3.6 \mathrm{mg} \mathrm{g} \mathrm{g}^{-1} \mathrm{~d}^{-1}$ ) occurring during August to November (Fig. 3).

Seasonal changes in blade dimensions (length and greatest width; Fig. 4) were similar to seasonal patterns of meristematic growth (Fig. 2). Maximum blade dimensions (ca $320 \times 25 \mathrm{~cm}$ ) occurred during June;
Fig. 2. Laminaria longicruris. Seasonal variations in meristematic growth rates (means \pm $\mathrm{SD}, \mathrm{cm} \mathrm{d}^{-1}$ ) (continuous line), and water temperatures (dashed line) at Black Ledge, Long Island Sound

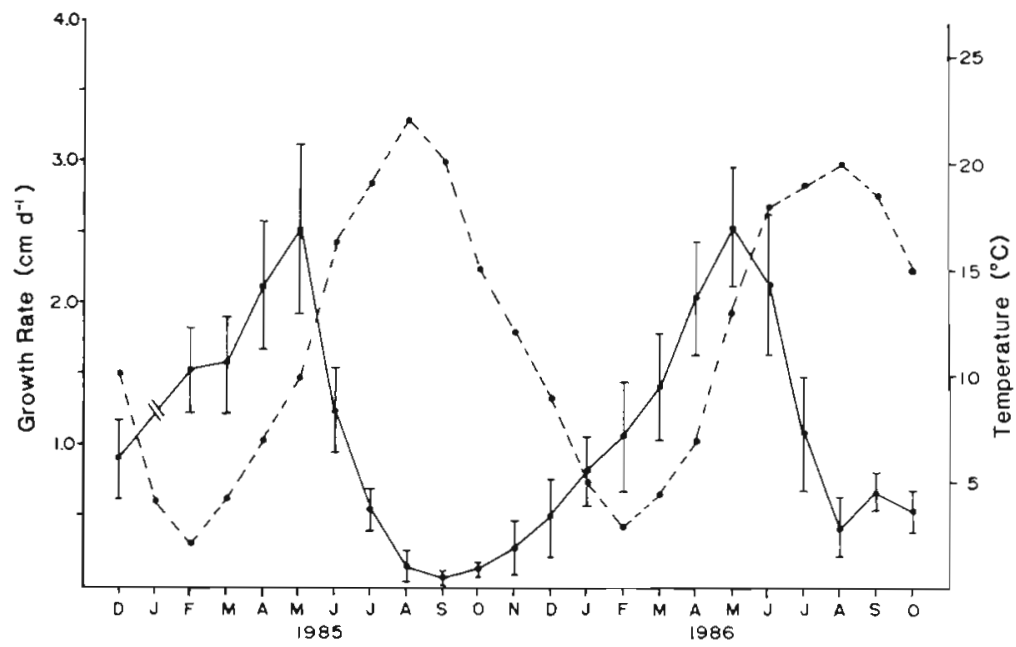




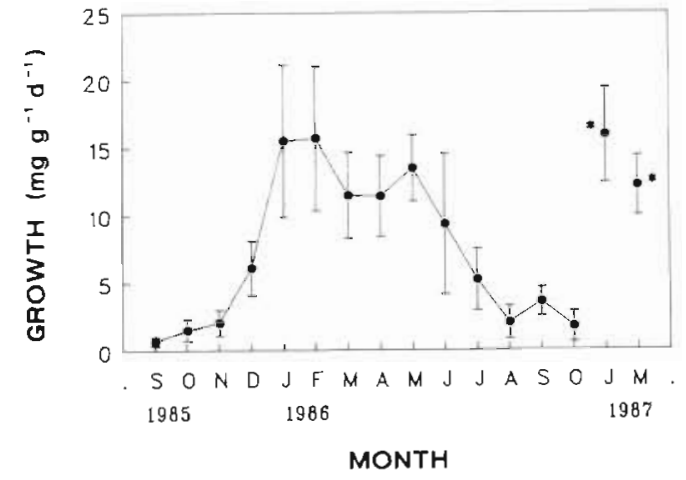

Fig. 3. Laminaria longicruris. Seasonal variations in growth rates ( $\mathrm{mg} \mathrm{g}^{-1} \mathrm{~d}^{-1}$, fresh weight) of plants from Long Island Sound. Asterisks: 2 non-continuous samples for January and May 1987. Data points are means $\pm \mathrm{SD}$
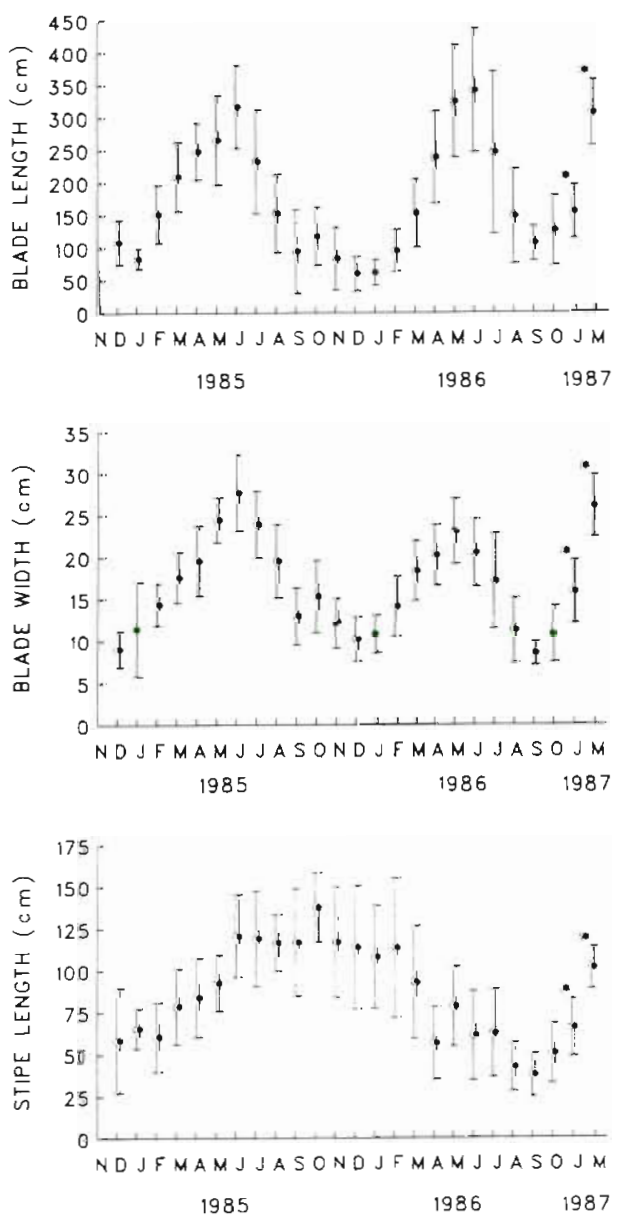

Fig. 4. Laminaria longicruris. Seasonal variations in blade length, blade width, and stipe length of plants from Long Island Sound. Asterisks: 2 non-continuous samples for January and May 1987. Data points are means \pm SD lowest values were observed during September to December (Fig. 4). Erosion of the tips and edges of blades occurred from July to September, which corresponded with periods of maximum temperatures and lowest growth rates (Fig. 2).

Seasonal variations also occurred in blade morphology. Ruffling of the outer edges of the blades commenced during December. Bullations (indentations or corrugations) were formed immediately above the meristematic zone in late December and January. Bullation and ruffle production terminated in April/May and May/June, respectively. Smooth plane blades, darker brown in colour, were initiated in the meristematic region during this period. These smooth plane blades persisted until December.

Blades were seriously weakened during June to August 1986 due to grazing activity by the prosobranch gastropod Lacuna vincta (Montagu). The density of $L$. vincta was 22 ind. $\mathrm{m}^{-2}$ of blade area in quadrats sampled in July 1986.

Carbon content of the blades was maximal during late summer and minimal during winter (Table 2). By contrast, nitrogen content was maximal during winter and minimal during summer (Table 2).

Stipe length increased from $60 \mathrm{~cm}$ in December 1984

Table 2. Laminaria longicruris. Carbon and nitrogen contents (mean [ $\pm \mathrm{SD}$ ] percent dry weights) of plants from Long Island Sound. Data are for median portions of 10 blades, $12 \mathrm{~cm}$ above blade/stipe juncture for each month

\begin{tabular}{llll|}
\hline Month & \multicolumn{2}{c}{ Carbon } & Nitrogen \\
\hline Jan & $27.53(3.96)$ & $2.61(0.17)$ \\
Feb & $30.78(4.25)$ & $2.55(0.26)$ \\
Mar & $31.03(2.32)$ & $1.92(0.19)$ \\
Apr & $33.29(3.13)$ & $2.07(0.20)$ \\
May & $30.28(1.79)$ & $2.06(0.36)$ \\
Jun & $30.63(2.62)$ & $1.80(0.15)$ \\
Jul & $33.67(2.62)$ & $1.60(0.28)$ \\
Aug & ND & ND \\
Sep & $37.77(1.54)$ & $1.80(0.15)$ \\
Oct & $34.78(3.53)$ & $2.07(0.27)$ \\
Nov & 34.46 & $(1.45)$ & $2.18(0.18)$ \\
Dec & $28.61(2.31)$ & $2.06(0.33)$ \\
Jan & $29.22(2.89)$ & $2.69(0.27)$ \\
Feb & $34.90(2.96)$ & $2.15(0.32)$ \\
Mar & $35.23(0.50)$ & $2.79(0.25)$ \\
Apr & ND & ND \\
May & $33.92(1.97)$ & $1.74(0.23)$ \\
Jun & $33.34(1.97)$ & $1.62(0.19)$ \\
Jul & $35.64(1.29)$ & $1.48(0.19)$ \\
Aug & $34.76(1.01)$ & $1.68(0.13)$ \\
Sep & 37.22 & $(1.01)$ & $1.68(0.13)$ \\
Oct & $29.99(1.52)$ & $1.77(0.16)$ \\
ND: not determined & & & \\
& & &
\end{tabular}




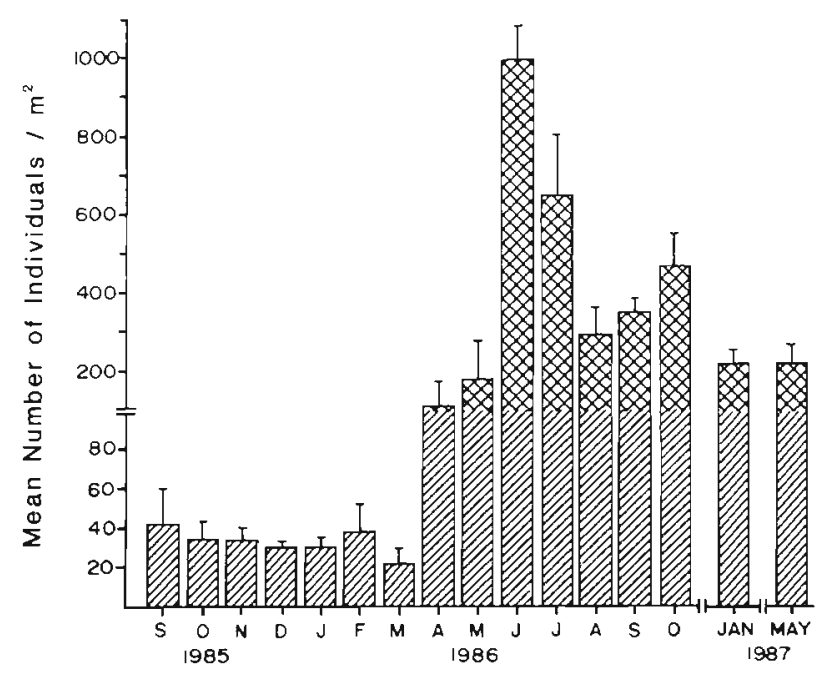

Fig. 5. Laminaria longicruris. Total density (mean $\pm \mathrm{SD}$ ) at Black Ledge, Long Island Sound. Cross hatching on upper portions of some bars corresponds with scale change on y-axis

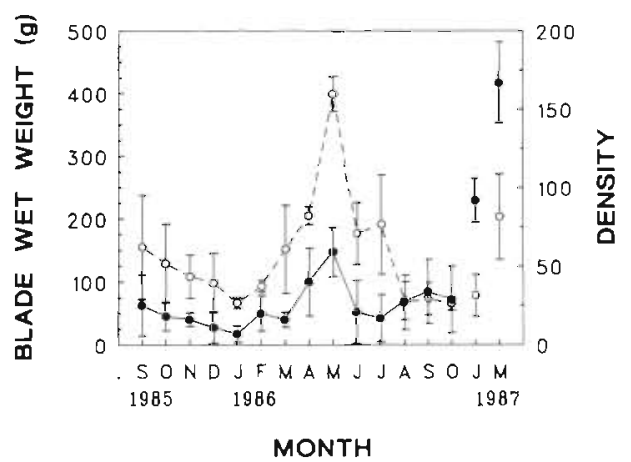

Fig. 6. Laminaria longicruris. Mean ( \pm SD) blade weight ( $g$ fresh weight) of individuals with blades $\geqslant 50 \mathrm{~g}$ sampled from quadrats $(c)$, and density $\mathrm{m}^{-2}$ with blades $\geqslant 50 \mathrm{~g}(\bullet)$ at Black Ledge, Long Island Sound. (J, M 1987 = January and May 1987)

to a maximum of $140 \mathrm{~cm}$ in October 1985 (Fig. 4). The highest rate of stipe growth occurred during May and June 1985.

\section{Density and biomass}

Lowest total plant density (25 to $44 \mathrm{~m}^{-2}$ ) occurred from September 1985 to March 1986 (Fig. 5). Blade weights and the density of individuals with blade weights $>50 \mathrm{~g}$ decreased from 25 to $7 \mathrm{~m}^{-2}$ during September to January (Fig. 6). Wet weights of these blades (Fig. 6) followed similar seasonal patterns to linear growth (Fig. 2) and blade dimensions (Fig. 4). Individual blade weights $\mathrm{m}^{-2}$ and plant density increased through May (Fig. 6). Increasing total densities of individuals occurred in April and June (Fig. 5). The density of plants with blades $\geqslant 50 \mathrm{~g}$ (Fig. 6) accounted for less than $2 \%$ of the almost 1000 plants $\mathrm{m}^{-2}$ in June (Fig. 5). The density of plants (Fig. 6) increased to $92 \mathrm{~m}^{-2}$ in January and $167 \mathrm{~m}^{-2}$ in May, comprising 46 and $84 \%$, respectively, of total plant densities.

Maximum biomass occurred during late spring/early summer (Fig. 7). The standing crop in May 1986 was $24 \mathrm{~kg} \mathrm{~m}^{-2}$ while it was only $2.5 \mathrm{~kg} \mathrm{~m}^{-2}$ in January 1986 . Stipes contributed more biomass than blades during September 1985 to February 1986 (Fig. 8). Total biomass values of 8 to $12 \mathrm{~kg} \mathrm{~m}^{-2}$ were maintained throughout summer 1986 (Fig. 7). Standing crop values for winter and late spring 1987 were much higher than those for 1986 (Figs. 7 and 8). The standing crop during May 1987 was $47 \mathrm{~kg} \mathrm{~m}^{-2}$.

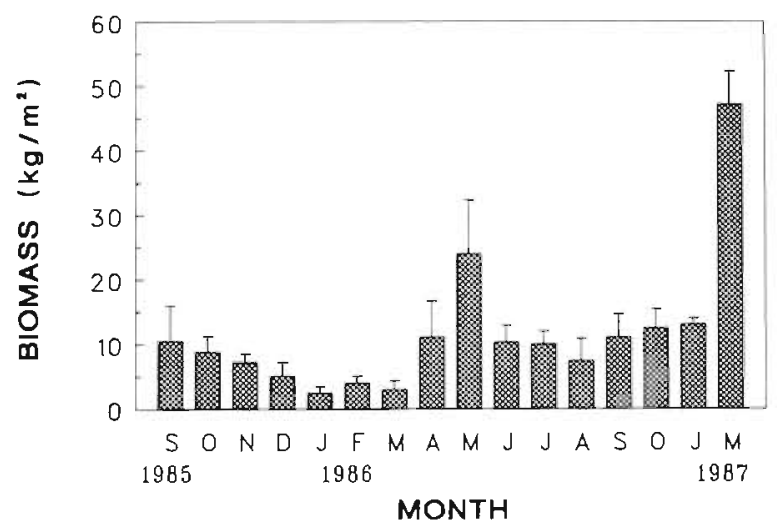

Fig. 7. Laminaria longicruris. Standing crop (biomass fresh weight, $\mathrm{kg} \mathrm{m}^{-2}$ ) at Black Ledge, Long Island Sound. (J, M 1987 = January and May 1987). Values are means $\pm S D$
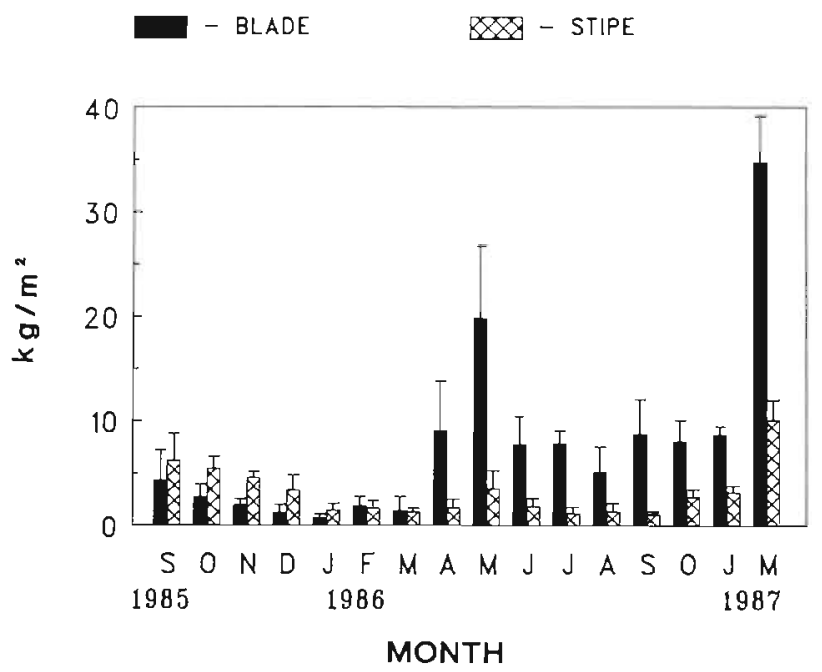

Fig. 8. Laminaria longicruris. Relative contributions $\left(\mathrm{kg} \mathrm{m}^{-2}\right.$, fresh weight) of blades and stipes to overall standing crop (Fig. 7) at Black Ledge, Long Island Sound. (J, M $1987=$ January and May 1987). Va.ues are means \pm SD 


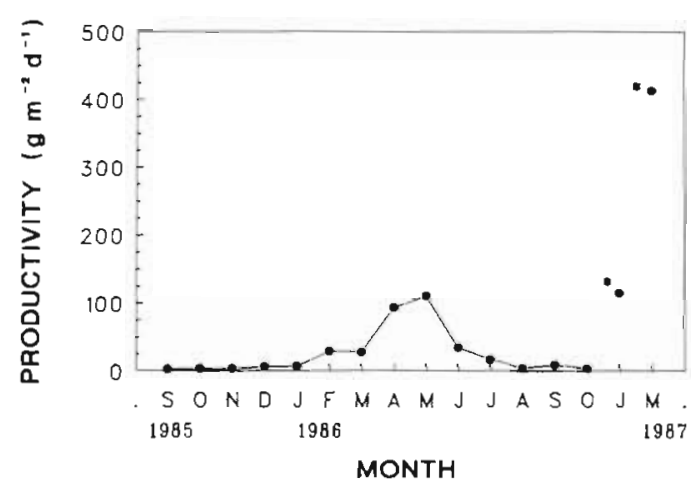

Fig. 9. Laminaria longicruris. Productivity $\left(\mathrm{g} \mathrm{m} \mathrm{m}^{-2} \mathrm{~d}^{-1}\right)$ of blades at Black Ledge, Long Island Sound. Asterisks: 2 noncontinuous samples for January and May 1987. Values are means; standard deviations (SD) were too small to be included

\section{Productivity}

Seasonal patterns in productivity (Fig. 9) were similar to those for linear growth (Fig. 2), blade dimensions (Fig. 4) and standing crop (Fig. 7). Highest productivity values were observed in spring $\left(110.53 \mathrm{~g} \mathrm{~m}^{-2} \mathrm{~d}^{-1}\right.$, May 1986; $413.32 \mathrm{~g} \mathrm{~m}^{-2} \mathrm{~d}^{-1}$, May 1987). Although there was little difference between the individual blade weights of January 1986 (66.7 g) and January 1987 (78.6 g) (Fig. 6), and between growth values (15.5, January 1986; $15.89 \mathrm{mg} \mathrm{g}^{-1} \mathrm{~d}^{-1}$, January 1987; Fig. 3) the relatively higher productivity in January $1987\left(115 \mathrm{~g} \mathrm{~m}^{-2}\right.$ $\mathrm{d}^{-2}$ ) was due to a higher population density during the latter month (Fig. 6). Similarly, productivity during May 1987 was influenced by high densities.

Seasonal trends in the production of sorus (reproductive) tissue on blades were also apparent (Fig. 10). Maximum production (75 to $90 \%$ ) occurred from October to December. The presence of sorus was relatively constant $(40$ to $55 \%$ ) during January to May 1985. In contrast, only 20 to $30 \%$ of plants were observed bearing sorus during January to April 1986 , increasing to $52 \%$ in May. Sorus production was always minimal during June to September (Fig. 10).
No conspicuous seasonal variations in seawater salinity and $\mathrm{pH}$ were observed; salinity and $\mathrm{pH}$ ranges were 30 to $33 \%$ and 7.9 to 8.3 , respectively.

\section{DISCUSSION}

Laminaria sporophytes are potentially perennial due to the survival of adult plants through successive years. Although Parke (1948) and Reynolds (1974) have reported life-spans of up to $3 y r$ in individuals, Parke (1948) demonstrated that the average life expectancy for L. saccharina in Great Britain was 2 yr. Chapman (1984) and Smith (1985) reported that the longevity of L. longicruris in Nova Scotia, Canada, was 25 and 20 mo, respectively. Populations of $L$. saccharina from LIS (Brinkhuis et al. 1983) and intertidal populations of the same species from British Columbia, Canada, (Druehl \& Hsiao 1977) were described as being annuals. Brinkhuis et al. (1983) attributed the annual behaviour of LIS populations to the loss of most sporophytes in summer because of high water temperatures. During our study we observed 2 new cohorts of plants populate the area, plants which attained and subsequently exceeded the minimum plant size class for sampling (> $1 \mathrm{~cm}$ ). The stipe data (Fig. 4) support these field observations that there were 3 successive macrosporophytic generations of $L$. longicruris at Black Ledge from December 1984 to May 1987. We will arbitrarily designate these as Generations \# 1, 2, and 3. We observed a decline in the density of large plants comprising the initial macrosporophytic generation from October 1985 to March 1986 (supported also by data in Fig. 6). The decrease in stipe lengths observed February to April 1986 (Fig. 4) would have been due to a replacement of one macrosporophytic generation (\# 1) with another developing macrosporophytic generation (\#2) having shorter stipes. The decrease in stipe lengths was not due to erosion. Stipes do not undergo periods of erosion and subsequent re-growth. Therefore, the overall annual stipe patterns do not

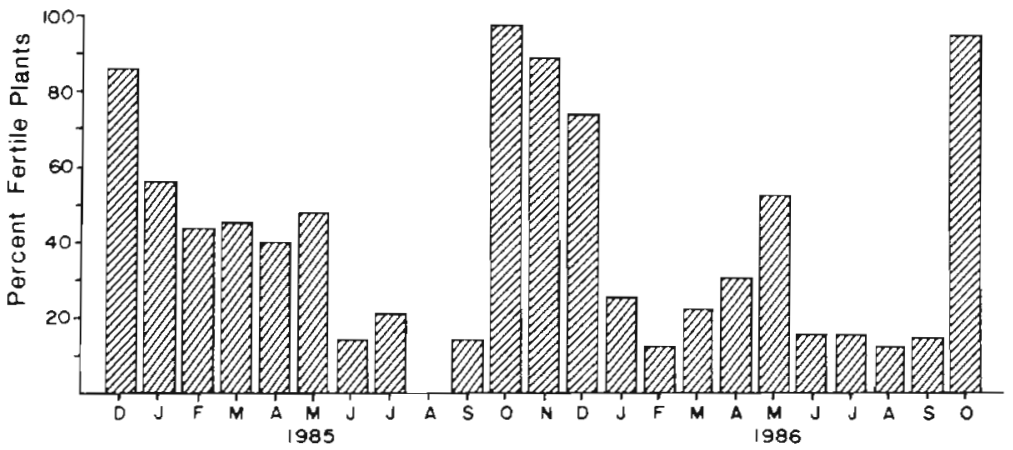

Fig. 10. Laminana longicruris. Percent sporophytes with blades $\geqslant 50 \mathrm{~g}$ possessing sorus tissue. Data are derived from the tagged population (December 1984 to September 1985) and standing crop quadrat samples (October 1985 to October 1986) 
higher optimal growth temperatures than others. Two of these isolates were from the vicinity of a nuclear power plant thermal outflow in LIS.

Growth of Laminaria longicruris (as $\mathrm{mg} \mathrm{g}^{-1} \mathrm{~d}^{-i}$ ) followed similar seasonal patterns to those presented for Ecklonia radiata (Kirkman 1984). Direct comparisons can be made in this case because wie employed identical methods to his. Overall, the growth of $L$. longicruris was slightly better (Fig. 3) than that of $E$. radiata (Fig. 7 of Kirkman 1984). During peak growth, values for $L$. longicruris exceeded those for E. radiata by ca $6.5 \mathrm{mg} \mathrm{g}^{-1} \mathrm{~d}^{-1}$. However, individual plant weights were higher for E. radiata.

The data presented here indicate an annual blade production of $10.6 \mathrm{~kg} \mathrm{~m}^{-2}$ during October 1985 to October 1986. Production during May 1987 alone was $12.8 \mathrm{~kg} \mathrm{~m}^{-2}$. It is clear that higher densities were attributable for the higher productivity in 1987 (January $1987=16 \times$ January 1986; May $1987=3.75 \times$ May 1986). We estimate an approximate annual production of 46 to $50 \mathrm{~kg} \mathrm{~m}^{-2}$ between October 1986 and October 1987 based upon trends from the previous year and 2 productivity values during 1987. Gerard \& Mann (1979) found an annual production of $10.6 \mathrm{~kg} \mathrm{~m}^{-2}$ for Laminaria longicruris in Nova Scotia while Kain (1977) reported a production value of $6.5 \mathrm{~kg} \mathrm{~m}^{-2} \mathrm{yr}^{-1}$ for Laminaria hyperborea (Gunn.) Fosl. off the Isle of Man, UK. The annual production of Ecklonia radiata in SW Australia was $27 \mathrm{~kg} \mathrm{~m}^{-2}$ (Kirkman 1984).

The mean standing crop of Laminaria longicruris (Fig. 7) varied with generation, season, and plant density. Highest values were $24 \mathrm{~kg} \mathrm{~m}^{-2}$ for Generation \# 2 in May 1986 and $46.8 \mathrm{~kg} \mathrm{~m}^{-2}$ for Generation \# 3 in May 1987. The standing crop in May 1985 (Generation \# 1) was $27.8 \mathrm{~kg} \mathrm{~m}^{-2}$ (Yarish \& Egan 1987). The standing crop of 1 -yr-old plants of Generation \# 3 in January 1987 was $13 \mathrm{~kg} \mathrm{~m}^{-2}$. Reported standing crop values for other localities are: $6.5 \mathrm{~kg} \mathrm{~m}^{-2}$ (Smith 1985 ) and $11 \mathrm{~kg}$ $\mathrm{m}^{-2}$ (Mann 1972a) for L. longicruris in Nova Scotia; $7.0 \mathrm{~kg} \mathrm{~m}^{-2}$ (Lüning 1969) and 10 to $20 \mathrm{~kg} \mathrm{~m}^{-2}$ (Kain 1977 ) for European populations of $L$. saccharina and $L$. hyperborea, respectively; 6 to $18 \mathrm{~kg} \mathrm{~m} \mathrm{~m}^{-2}$ for Ecklonia radiata in SW Australia (Kirkman 1984); and 3 to $22 \mathrm{~kg}$ $\mathrm{m}^{-2}$ for Macrocystis pyrifera (L.) C. Agardh in Southern and Baja Califomia (North 1957). Grua (1964) obtained an average $140 \mathrm{~kg} \mathrm{~m}^{-2}$ for $M$. pyrifera in the Kerguelen Archipelago. However, this value was influenced by high densities of fronds.

Although the density of young recruits was $1000 \mathrm{~m}^{-2}$ in June 1986 (Fig. 5), the number of plants with blades $\geqslant 50 \mathrm{~g}$ stabilized between 92 and $167 \mathrm{~m}^{-2}$ during the third quarter of the life-span of Generation \# 3 (Fig. 6). Up to 800 ind. $\mathrm{m}^{-2}$ of Laminaria saccharina have been reported for Rhode Island (Brady-Campbell et al. 1984). The highest density of Ecklonia radiata in Kirkman's
(1984) study was $60 \mathrm{~m}^{-2}$. The density of $L$. longicruris in SW Nova Scotia, which was constant through 1 yr, was $1.2 \mathrm{~m}^{-2}$ (Chapman 1984). On the other hand, Gerard \& Mann (1979) reported densities of 8 and 24 ind. $\mathrm{m}^{-2}$ for sheltered and exposed sites, respectively, in Nova Scotia.

Grazing of Laminaria populations by Lacuna vincta has been reported previously (Fralick et al. 1974, Brady-Campbell et al. 1984, Johnson \& Mann 1986). Although present throughout the study period, the snail reached its highest densities during the summer of 1986. Johnson \& Mann (1986) found that elevated levels of polyphenols in $L$. longicruris inhibited grazing by $L$. vincta. Perhaps annual $L$. longicruris plants have different overall polyphenol concentrations than perennial plants (Yarish \& Egan 1987) which would imply that the population dynamics of $L$. Iongicruris and $L$. vincta are closely interconnected.

Seasonal changes in blade morphology, observed during the present study, have also been reported elsewhere. Setchell (1900) wrote 'In $L$. agardhii and $L$. saccharina of the New England coast (North America), the writer has found that the summer form is usually ample, with ruffles and rows of indentations fully developed; but in August a change takes place and this summer blade is replaced by a winter blade which is perfectly plane and devoid of both these features. Again, in the spring, this plane blade is replaced by the ruffled and indented form'. In contrast to Setchell's (1900) observations, the bullate (indented) form was produced in winter (January) being replaced by the plane blade form in summer (June), during the present study.

Lüning (1975) and Lüning et al. (1978) reported genetic differentiation between European populations of Laminaria saccharina with regard to blade morphology. A smooth plane blade form appears restricted to the Baltic Sea, the west coast of Sweden, and Helgoland, North Sea (see Lüning 1975, Lüning et al. 1978), while the bullate form is found throughout the remainder of the range for the species. In crosses between the plane and bullate forms the offspring always possessed bullations; nonbullate plants always bred true (Lüning 1975, Lüning et al. 1978, Bolton et al. 1983). However, Lüning (pers. comm.) has produced offspring from crosses of $L$. saccharina from Espegrend, Norway. exhibiting seasonal dimorphism of blade morphology.

We hypothesize that the seasonal changes in blade morphology are temperature/temperature-photoperiod related responses and are survival adaptations for temperature extremes such as those found in the LIS region. A smooth plane blade form would have less surface area exposed to its adverse surroundings. McMillan \& Bridges (1982) reported variable leaf morphologies in the Pacific seagrass Halophila ovalis 
(R.Br.) Hook. f. var. bullosa Setchell due to temperature. Exposure to high temperatures resulted in more leaf damage to plants with bullate leaves. In addition, plants with bullate leaves produced smooth leaves after exposure to high temperatures. Bullate leaf production was resumed after the temperature was lowered (McMillan \& Bridges 1982). Lüning et al. (1978) reported that the bullate form of Laminaria saccharina died at temperatures above $16^{\circ} \mathrm{C}$, whereas the plane form from Helgoland tolerated $18^{\circ} \mathrm{C}$. Ardré (1971) reported morphological variations of $L$. saccharina blades at Montedor, Portugal, where summer water temperatures exceed $16^{\circ} \mathrm{C}$. The absence of, or lack of production of, the bullate form in Helgoland and parts of the Baltic may also in some way be light-related. 'Arctic conditions' (in relation to light availability) occur from October to February in these areas (see Lüning 1985).

Sorus formation most commonly occurs during autumn and winter in both Laminaria longicruris (Chapman 1973) and L. saccharina (Parke 1948, Kain 1979). The sudden appearance of sorus and high percentages of plants bearing sorus in October (Fig. 10) is somewhat similar to the sudden and synchronous sorus formation in Saccorhiza dermatodea (Pyl.) J. Ag. in Newfoundland (Keats \& South 1985). The latter authors suspected the phenomenon was under photoperiodic control. Lüning (1988) has shown that sorus formation in L. Saccharina from Helgoland is indeed a short-day response. However, L. saccharina in LIS undergoes 2 peak periods (spring and autumn) of sorus formation (Lee \& Brinkhuis 1986). Although some tagged individuals in the present study, and monitored through 1985, also behaved in a similar manner to $L$. saccharina, this was not the case for the different generations in general. The reproductive peaks observed in late autumn (1984 and 1985; Fig. 10) would have been produced by Generation \# 1 . The peak observed during October to December 1985 was also at the end of the 2 yr cycle for Generation \# 1. Then the low percentages of fertile sporophytes observed during January to March 1986 (Fig. 10) would not have been due to a hiatus in sorus formation but rather reflected succession by plants of Generation \#2. Generation \#2 became reproductive near the end of its 1 yr cycle in May 1986 before being succeeded by Generation \# 3 .

Lüning (1988) contends that LIS populations may be comprised of day-neutral plants or that short-day conditions are not essential for, but may promote sorus formation. We propose that sorus formation in LIS plants is probably a short-day response. However, low winter temperatures may block the effects of the initial stimulus (hence the winter hiatus in sorus production) until water temperatures increase again in spring. The above would not explain the continued sorus produc- tion from autumn 1984 through May 1985 by Generation \#1 (Fig. 10). Perhaps the physiologies of the annual and perennial plants are fundamentally different.

In conclusion, Laminaria longicruris at its southern limit in the western Atlantic Ocean is as productive as, or even more productive than other kelp species worldwide. Furthermore, the productivity measurement methodology of Mann \& Kirkman (1981) is easily used for studies on Laminaria species with non-digitate blades.

Acknowledgements. This research was supported by a grant to C. Yarish from NOAA Office of Sea Grant, Department of Commerce, under Grant no. NA85AA-D-SG101, the Connecticut Sea Grant Programme. The US Government is authorized to produce and distribute reprints for governmental purposes notwithstanding any copyright notation that may appear herein. The authors are grateful to C. Appel, D. Moffat, R. De Goursey, A. Lima and M. J. Spring. The authors are also grateful to the late B. H. Brinkhuis and P. F. Egan as well as to H. Kirkman, F. R. Trainor, A. C. Mathieson and J. A. Kilar for their discussions and assistance.

\section{LITERATURE CITED}

Anderson, M. R., Cardinal, A., Larochelle, J. (1981). An alternate growth pattern for Laminaria longicruris. J. Phycol. 17: $405-411$

Ardré, F. (1971). Contribution a l'etude des algues marines du Portugal. Bull. Cent. Étude. Rech. scient. Biarritz 8: $359-574$

Boden, G. T. (1979). The effect of depth on summer growth of Laminaria saccharina (Phaeophyta, Laminariales). Phycologia 18: 405-408

Bolton, J. J., Lüning, K. (1982). Optimal growth and maximal survival temperatures of Atlantic Laminaria species (Phaeophyta) in culture. Mar Biol. 66: 89-94

Bolton, J. J., Germann, I., Lüning, K. (1983). Hybridization between Atlantic and Pacific representatives of the Simplices section of Laminaria (Phaeophyta). Phycologia 22: $133-140$

Brady-Campbell, M. M. Campbell, D. B., Harlin, M. M. (1984). Productivity of kelp (Laminaria spp.) near the southern limit in the Northwestern Atlantic Ocean. Mar. Ecol. Prog. Ser. 18: 79-88

Brinkhuis, B. H., Breda, V., Tobin, S., Macler, B. A. (1983). New York Marine Biomass Program - culture of Laminaria saccharina. J. Wld Maricult Soc. 14: 360-379

Brinkhuis, B. H., Mariani, E. C., Breda, Y. A., Brady-Campbell, M. M. (1984). Cultivation of Laminaria saccharina in the New York Marine Biomass Program. Hydrobiologia 116/ 117: $266-271$

Brinkhuis, B. H., Levine, H. G., Schlenk, C. G., Tobin, S. (1987). Laminaria cultivation in the far east and North America. In: Bird, K. T., Benson, P. H. (eds.) Seaweed cultivation for renewable resources. Elsevier, Amsterdam, p. $107-146$

Burrows, E. M., Pybus, D. (1971). Laminaria saccharina and marine pollution in North East England. Mar. Pollut. Bull. 2: $53-56$ 
Chapman, A. R. O. (1973). Phenetic variability of stipe morphology in relation to season, exposure, and depth in the non-digitate complex of Laminaria Lamour. (Phaeophyta, Laminariales) in Nova Scotia. Phycologia 12: 53-57

Chapman, A. R. O. (1974). The genetic basis of morphological differentiation in some Laminaria populations. Mar. Biol. 24: $85-91$

Chapman, A. R. O. (1984). Reproduction, recruitment and mortality in two species of Laminania in Southwestern Nova Scotia. J. exp. mar. Biol. Ecol. 78: 99-109

Chapman, A. R. O. (1987). The wild harvest and culture of Laminaria longicruris de la Pylaie in Eastern Canada. In: Doty, M. S., Caddy, J. F., Santelices, B. (eds.) Case studies of seven commercial seaweed resources. FAO Fish. Tech. Pap. 281: 193-237

Chapman, A. R. O., Craigie, J. S. (1977). Seasonal growth in Laminaria loncicruris; relations with dissolved inorganic nutrients and internal reserves of nitrogen. Mar. Biol. 40: $197-205$

Chapman, V. J., Chapman, D. J. (1980). Seaweeds and their uses. Chapman and Hall Ltd, New York

Druehl, L. D., Hsiao, S. I. C. (1977). Intertidal kelp response to seasonal environmental changes in a British Columbia inlet. J. Fish. Res. Bd Can. 34: 1207-1211

Egan, B., Garcia-Ezquivel, Z., Brinkhuis, B. H., Yarish, C. (1990). Genetics of morphology and growth in Laminaria from the North Atlantic Ocean - implications for biogeography. In: Garbary, D., South, G. R. (eds.) SpringerVerlag, New York, p. 147-171

Egan, B., Yarish, C. (1988). The distribution of the genus Laminaria (Phaeophyta) at its southern limit in the western Atlantic Ocean. Botanica mar. 31: 155-161

Egan, B., Vlasto, A., Yarish, C. (1989). Seasonal acclimation to temperature and light in Laminaria longicruris de la Pyl. (Phaeophyta). J. exp. mar Biol. Ecol. 129: 1-16

Fralick, R. A., Turgeon, K. W. Mathieson, A. C. (1974). Destruction of kelp populations by Lacuna vincta (Montagu). Nautilus 88: 112-114

Gagné, J., Mann, K., Chapman, A. R. O. (1982). Seasonal patterns of growth and storage in Laminaria longicruris in relation to differing patterns of availability of nitrogen in the water. Mar. Biol. 69: 91-101

Gendron, L. (1985). Conversion of blade length into biomass production estimates in Laminaria longicruris. Can. J. Fish. Aquat. Sci. 42: 33-37

Gerard, V. A., Du Bois, K. R. (1988). Temperature adaptation in a southern boundary population of the kelp, Laminaria saccharina. Mar. Biol. 97: 575-580

Gerard, V. A., Mann, K. H. (1979). Growth and production of Laminaria longicruris (Phaeophyta) populations exposed to different intensities of water movement. J. Phycol. 15: 33-41

Grua, P. (1964). Premieres donnees sur les biomasses de l'herbik:r a Macrocystis pyrifera de la baie du Morbihan (Archipel Kerguelen). La Terre et la Vie 2: 215-220

Hoek, C. van den (1982). The distribution of benthic marine algae in relation to the temperature regulation of their life histories. Biol. J. Linn. Soc. 18: 81-144

Johnson, C. R., Mann, K. H. (1986). The importance of subtidal seaweed communities: the kelp Laminaria longicruris de la Pylaie survives grazing by the snall Lacuna vincta (Montagu) at high population densities. J. exp. mar Biol. Ecol 97: 231-267

Kain, J. M. (1977). The biology of Laminaria hyperborea. The effect of depth on some populations. J. mar. biol. Ass. U.K. $57 \cdot 587-607$

Kain, J. M. (1979). A view of the genus Laminaria. Oceanogr mar. Biol. A. Rev. 17: 101-161
Keats, D. W., South. G. R. (1985). Aspects of reproductive phenology of Saccorhiza dermatodea (Phaeophyta, Laminariales) in Newfoundland. Br. phycol. J. 20: 117-122

Kirkman, H. (1984). Standing stock and production of Eck Ionia radiata (C. Ag.) J. Agardh. J. exp. mar. Biol. Ecol. 76 $119-130$

Lee, J. A., Brinkhuis, B. H. (1986). Reproductive phenology of Laminaria saccharina (L.) Lamour. (Phaeophyta) at the southern limit of its distribution in the northwestern Atlantic Ocean. J. Phycol. 22: 276-285

Lee, J. A., Brinkhuis, B. H. (1988). Effect of temperature and light on gametogenesis of Laminaria saccharina at its southern limit of distribution in the Western Atlantic Ocean. J. Phycol. 24: 181-191

Lüning, K. (1969). Standing crop and leaf area index of the sublittoral Laminaria species near Helgoland. Mar, Biol. 3: 282-286

Lüning, K. (1975). Kreuzungsexperimente an Laminaria saccharina von Helgoland und von der Isle of Man. Helgoländer wiss. Meeresunters. 27: 108-114

Lüning, K. (1979). Growth strategies of three Laminaria species (Phaeophyceae) inhabiting different depth zones in the sublittoral region of Helgoland (North Sea). Mar. Ecol. Prog. Ser. 1: 195-207

Lüning, K. (1985). Meeresbotanik. Verbreitung, Ökophysiologie, und wirtschaftliche Bedeutung der marinen Makroalgen. Thieme Verlag, Stuttgart

Lüning, K. (1988). Photoperiadic control of sorus formation in the brown alga Laminaria saccharina. Mar. Ecol. Prog. Ser 45: $137-144$

Lüning, K., Chapman, A. R. O., Mann, K. H. (1978). Crossing experiments in the non-digitate complex of Laminaria from both sides of the Atlantic. Phycologia 17: $293-298$

Mann, K. H. (1972a). Ecological energetics of the seaweed zone in a marine bay on the Atlantic coast of Canada. I. Zonation and biomass of seaweeds. Mar. Biol. 12: $1-10$

Mann, K. H. (1972b). Ecological energetics of the seaweed zone in a marine bay on the Atlantic coast of Canada. II Productivity of the seaweeds. Mar Biol. 14: 199-209

Mann, K. H., Kirkman, H. (1981). Biomass method for measuring productivity of Ecklonia radiata, with the potential for adaptation to other large brown algae. Aust. J. mar. Freshwat. Res. 32: 297-304

Mann, K. H., Mann, C. (1981). Problems of converting linear growth increments of to estimates of biomass production. Xth Int. Seaweed Symp.: 699-704

McMillan, C., Bridges, K. W. (1982). Systematic implications of bullate leaves and isozymes for Halophila from Fijı and Western Samoa. Aquat. Bot. 12: 173-188

North, W. J. (1957). Experimental ecology. Kelp Invest. Prog. Prog. Rep. 1 July-30 Sept, Univ. Calif., Inst. Mar Res. IMR Ref. 57: $11-28$

Okazaki, A. (1971). Seaweeds and their uses in Japan. Tokal University Press, Tokyo

Parke, M. (1948). Studies on Britısh Laminariaceae. I. Growth in L. saccharina (L.) Lamour J. mar biol. Ass. U.K. 27 $651-709$

Pringle, J. D., Sharp. G. J. (1980). Multispecies resource management of economically important marine plant communities of eastern Canada. Helgoländer Meeresunters. 33: $711-720$

Reymolds, N. B. (1974). The growth of some New England perennial seaweeds. Rhodord 76:59-63

Riley, G. A. (1959). Oceanography of Long Island Sound 1954-1955. Bull. Bingham oceanogr Coll. 17.9-30 
Riley, G. A. (1961). Review of the oceanography of Long Island Sound. Deep Sea Res. 3 (Suppl.): 224-238

Setchell, W A. (1900). Critical notes on the New England species of Laminaria. Rhodora 2: 115-119

Smith, B. D. (1985). Recovery following experimental harvesting of Laminaria longicruris and L. digitata in Southwestern Nova Scotia. Helgoländer Meeresunters. 39: $83-101$

Tseng, C. K. (1981). Commercial cultivation. In: Lobban, C., Wynne, M. (ed.) Biology of seaweeds. Univ. California Press, Berkeley, p. 680-725

Wilce, R. T. (1965). Studies on the genus Laminaria. III. A revision of the North Atlantic species of the Simplices section of Laminaria. Botanica, Gotheburg 3: 247-256

Yarish, C., Egan, B. (1987). Biological studies on Laminaria longicruris and its aquaculture potential in Long Island

This article was submitted to the editor
Sound. In: Halasi-Kun, G. J. (ed.) Columbia University seminars pollution and water resources, Vol. 20: 189-215. Columbia University Press, New York

Yarish, C., Egan, B. (1989). The biology of Laminaria longicruris and its potential for mariculture in Long Island Sound. In: Kanungo, K., Brousseau, D., Singletory, R., Liscek, L. (eds.) 2nd Conference on the Aquatic Environment: Problems and Perspectives. Western Connecticut State University, Danbury, CT, p. 55-89

Yarish, C, Brinkhuis, B. H., Egan, B., Garcia-Ezquivel, Z. (1990). Morphological and physiological bases for Laminaria selection protocols in Long Island Sound aquaculture. In: Yarish, C., Penniman, C., van Patten, M. (eds.) Economically important marine plants of the Atlantic: their biology and cultivation. Connecticut Sea Grant Symposium, Groton, p. 53-94

Manuscript first received: December 1, 1989

Revised version accepted: July 13,1990 